SUBJECT AREAS:

TECTONICS

PALAEOMAGNETISM

GEOLOGY

GEODYNAMICS

Received

22 March 2013

Accepted

10 July 2013

Published

1 August 2013

Correspondence and requests for materials should be addressed to M.M. (m.maffione@ uu.nl)

* Current address: Paleomagnetic Laboratory Fort

Hoofddijk, Department of Earth Sciences,

University of Utrecht,

Budapestlaan 17,

3584 CD Utrecht, The Netherlands.

\section{Recognizing detachment-mode seafloor spreading in the deep geological past}

\author{
Marco Maffione*, Antony Morris \& Mark W. Anderson
}

School of Geography, Earth and Environmental Sciences, Plymouth University, Drake Circus, Plymouth PL4 8AA, UK.

Large-offset oceanic detachment faults are a characteristic of slow- and ultraslow-spreading ridges, leading to the formation of oceanic core complexes (OCCs) that expose upper mantle and lower crustal rocks on the seafloor. The lithospheric extension accommodated by these structures is now recognized as a fundamentally distinct "detachment-mode" of seafloor spreading compared to classical magmatic accretion. Here we demonstrate a paleomagnetic methodology that allows unequivocal recognition of detachment-mode seafloor spreading in ancient ophiolites and apply this to a potential Jurassic detachment fault system in the Mirdita ophiolite (Albania). We show that footwall and hanging wall blocks either side of an inferred detachment have significantly different magnetizations that can only be explained by relative rotation during seafloor spreading. The style of rotation is shown to be identical to rolling hinge footwall rotation documented recently in OCCs in the Atlantic, confirming that detachment-mode spreading operated at least as far back as the Jurassic.

$\mathrm{t}$ is now known that large-offset detachment faulting plays a fundamental role in accommodating plate separation at slow- and ultraslow- spreading mid-ocean ridges ${ }^{1-7}$. For example, recent work ${ }^{3}$ has concluded that more than $50 \%$ of the Mid-Atlantic Ridge between $12.5^{\circ} \mathrm{N}$ and $35^{\circ} \mathrm{N}$ is affected by such faulting. Recognition of the widespread occurrence and significance of these structures has led to definition of a new "Chapman" detachment-mode of seafloor spreading. The uplifted footwalls of oceanic detachment faults are known as oceanic core complexes (OCCs) ${ }^{2-7}$. They are elevated, dome-shaped massifs, typically with prominent spreading-parallel corrugations on smoothly curved upper surfaces (Fig. 1). These surfaces represent exposed, now-inactive low-angle fault planes that have been directly responsible for the exhumation of mantle and plutonic lithologies onto the seafloor. Paleomagnetic analyses of OCC footwall sections sampled by scientific ocean drilling along the Mid-Atlantic Ridge ${ }^{9-11}$ have demonstrated that this unroofing is characteristically accommodated by tectonic rotation around ridge-parallel, shallowly plunging axes, consistent with flexural, isostatic rolling-hinge deformation ${ }^{12,13}$.

Given the widespread occurrence of oceanic detachment faults and associated OCCs in young lithosphere close to present day spreading axes, there is clearly a need to establish whether this mode of spreading was also significant in the deep geological past. Exposed OCC footwall sections have only been identified and directly sampled in young $(<11 \mathrm{Ma})$ lithosphere ${ }^{2,5-7,9-11}$. Older oceanic detachment systems in in situ lithosphere are obscured beneath marine sedimentary successions, but fault systems that are geometrically compatible with detachment-mode spreading have been imaged by seismic reflection experiments in Cretaceous oceanic crust in the eastern Central Atlantic ${ }^{14}$. To extend this record to older geological time periods, it is necessary to search for potential examples of detachment-mode fault systems in ancient oceanic lithosphere preserved in ophiolites. However, recognition of these structures in ophiolites requires separation of seafloor spreading and emplacement-related tectonic signatures, as primary seafloor morphologies are rarely preserved in ophiolites. This can only be achieved by linking evidence for tectonic juxtaposition and relative rotation of upper crustal and lower crustal/upper mantle sequences to kinematic constraints in an original seafloor frame of reference.

We illustrate this approach using an example from the northern Mirdita ophiolite of Albania. This is a slice of Jurassic (c. $165 \mathrm{Ma}^{15}$ ) oceanic lithosphere, representing a remnant of the eastern branch of the slow-spreading Tethys Ocean that was obducted during Europe-Adria convergence ${ }^{15,16}$. It consists of a partially serpentinized lherzolitic mantle sequence (containing discrete gabbro intrusions) overlain tectonically by an upper crustal sequence of sheeted dikes and lavas (Fig. 2) ${ }^{17}$. The contact between mantle and upper crustal rocks in the region of the Puka Massif is locally marked by mylonitic shear zones in amphibole-bearing peridotites ${ }^{17,18}$. These field relationships ${ }^{17,19}$ may result from either (a) detachment-mode spreading and associated mantle exhumation (as 


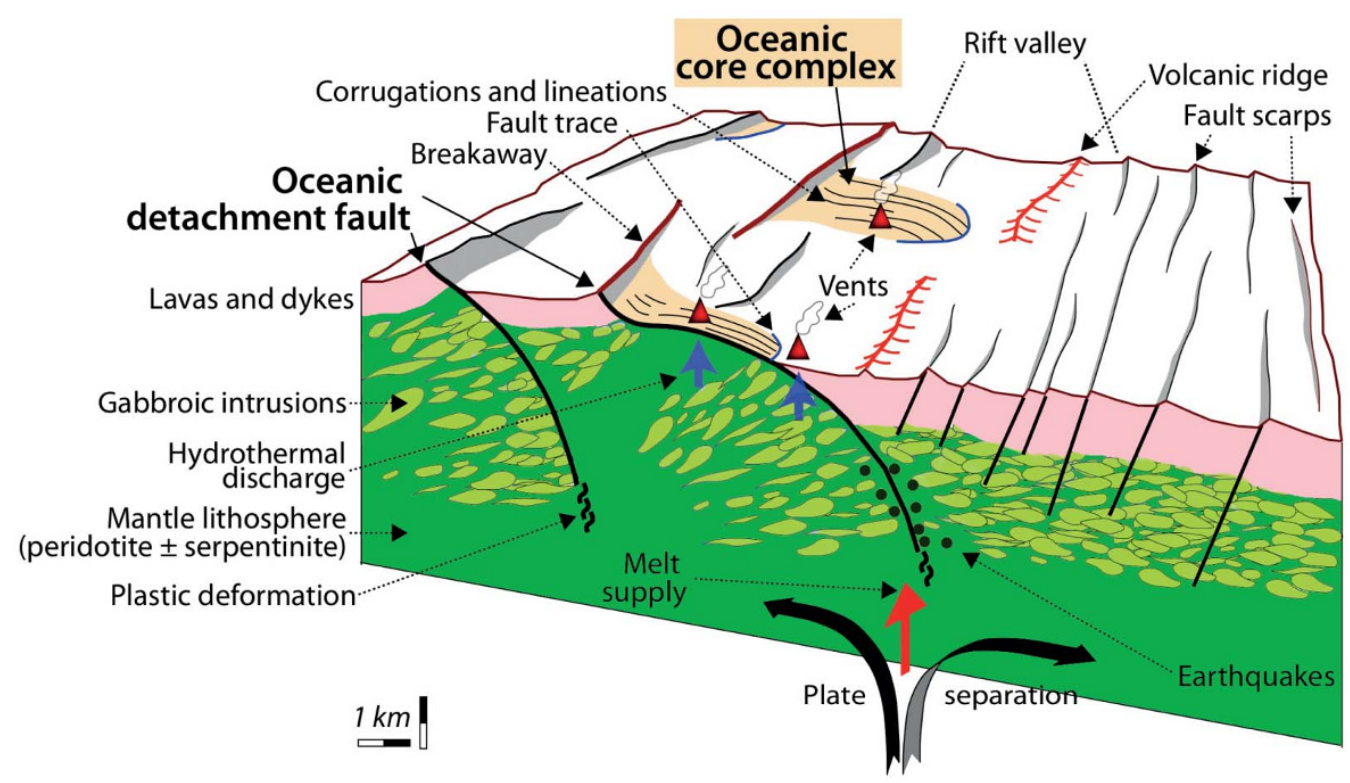

Figure $1 \mid$ The "Chapman model"s of lithospheric accretion and oceanic core complex formation dominated by detachment faulting. In this newly recognized mode of seafloor spreading, plate separation is accommodated by displacement on large-slip detachment faults, leading to rotation of fault footwalls, exhumation of mantle lithosphere, and the formation of oceanic core complexes.

seen in modern OCCs $^{1-8}$ ) or (b) local tectonic excision of the lower crustal section during ophiolite obduction or post-emplacement deformation. These alternatives may be resolved by detection of OCC-type relative rotation of detachment footwall and hanging wall sections around a ridge-parallel axis, as seen in in situ OCCs in Atlantic lithosphere. Such rotation cannot be detected from field observations alone as paleohorizontal indicators are typically absent in ophiolitic rocks, but can be quantified using magnetic remanence vectors from footwall and hanging wall blocks. Here we combine paleomagnetic detection of relative rotation with field structural data from the Mirdita sheeted dike complex to show that the geometry and kinematics of rotation are consistent with OCC-style flexural, isostatic rolling-hinge ${ }^{12,13}$ deformation. This extends the record of "Chapman"s detachment-mode spreading back to the Jurassic, to the age limit of in situ oceanic lithosphere on Earth.

\section{Results}

We sampled gabbroic intrusions and variably serpentinized host peridotites in the upper mantle footwall sequence of the inferred Mirdita detachment fault around the Puka Massif, and basaltic sheeted dikes, pillow lavas and sheet flows and cross-cutting dikes in the upper crustal hanging wall sequence (Fig. 2). Demagnetization experiments were used to isolate magnetic remanences of the sampled specimens and rock magnetic techniques used to determine the nature of the main magnetic carriers (see Methods). Stable magnetization directions were obtained at 25 upper mantle and upper crustal sites. Typical examples of demagnetization behaviour for each lithology are illustrated in Figure 3a-e. Rock magnetic experiments and demagnetization characteristics indicate that multidomain titanomagnetite and titanomaghemite are the main magnetic carriers in the upper crustal lithologies, whereas single-domain to pseudosingle-domain magnetite and low-titanium titanomagnetite are responsible for the magnetization of gabbros and peridotites. Mean in situ directions of magnetization for mantle peridotites (PP) and mantle-hosted gabbro intrusions (GA) of the Puka Massif and for upper crustal sheeted dikes (SD) and lavas/discrete dikes (LD) are shown in Figure 3f. These directions are significantly different from the present-day magnetic field direction at the sampling locality (D $=0^{\circ}, \mathrm{I}=61^{\circ}$ ), and are interpreted as ancient remanences.
The timing of remanence acquisition is difficult to constrain using paleomagnetic tilt tests in ophiolitic terranes due to the lack of unequivocal paleohorizontal surfaces in extrusive rocks and the potential for components of tilting around dike-normal axes in sheeted dikes ${ }^{20}$. However, remanence acquisition during or shortly after formation by seafloor spreading in the upper crustal sites is supported by: (i) the presence of normal (10 sites) and reversed (4 sites) polarities of remanence, consistent with rapid polarity changes in the Jurassic ${ }^{21}$ and inconsistent with pervasive later remagnetization; and (ii) mean inclinations of the upper crustal sites (in both in situ and tilt corrected coordinates) consistent with that expected from the Jurassic ( $170 \mathrm{Ma}$ ) European paleomagnetic pole ${ }^{22}$, assuming the ophiolite is associated with the European, overriding plate of the Tethys realm during intraoceanic subduction.

The gabbros within the mantle sequence in the footwall block carry a high temperature, single component remanence of reversed polarity that unblocks close to the magnetite Curie temperature $\left(580^{\circ} \mathrm{C}\right.$, with only limited unblocking below $525^{\circ} \mathrm{C}$; Fig. 3e). These discrete, high unblocking temperature spectra are consistent with remanence characteristics of gabbros recovered by scientific ocean drilling ${ }^{10,23,24}$ and compatible with a primary thermoremanence carried by nearly pure, single-domain magnetite. Also, the lack of alteration of the gabbros precludes acquisition of significant postemplacement chemical remanence by these rocks.

The footwall gabbros (GA in Fig. 3f) and hanging wall upper crustal section (SD and LD in Fig. 3f) record statistically different magnetization directions. The NNE magnetization of the hanging wall sequence reflects a $45^{\circ}$ clockwise regional rotation of the Albanides during the Tertiary ${ }^{25}$, whereas ENE magnetizations of the footwall gabbros require additional substantial rotation relative to the hanging wall. In contrast to the reversely magnetized footwall gabbros, the host mantle carries a normal polarity remanence (Fig. 3d) with a significantly different direction to that of the gabbros (Fig. 3f). Hence, remanences in different footwall units within the Puka Massif were acquired at different times. The relative ages of magnetization are clearly constrained by detailed sampling of a $<$ 2 m interval across a sharp intrusive contact (sites PU05/06 in Fig. 2), where significantly different magnetization directions are observed right up to the contact. The remanence of the host mantle peridotites must postdate gabbro emplacement, as any remanence acquired 


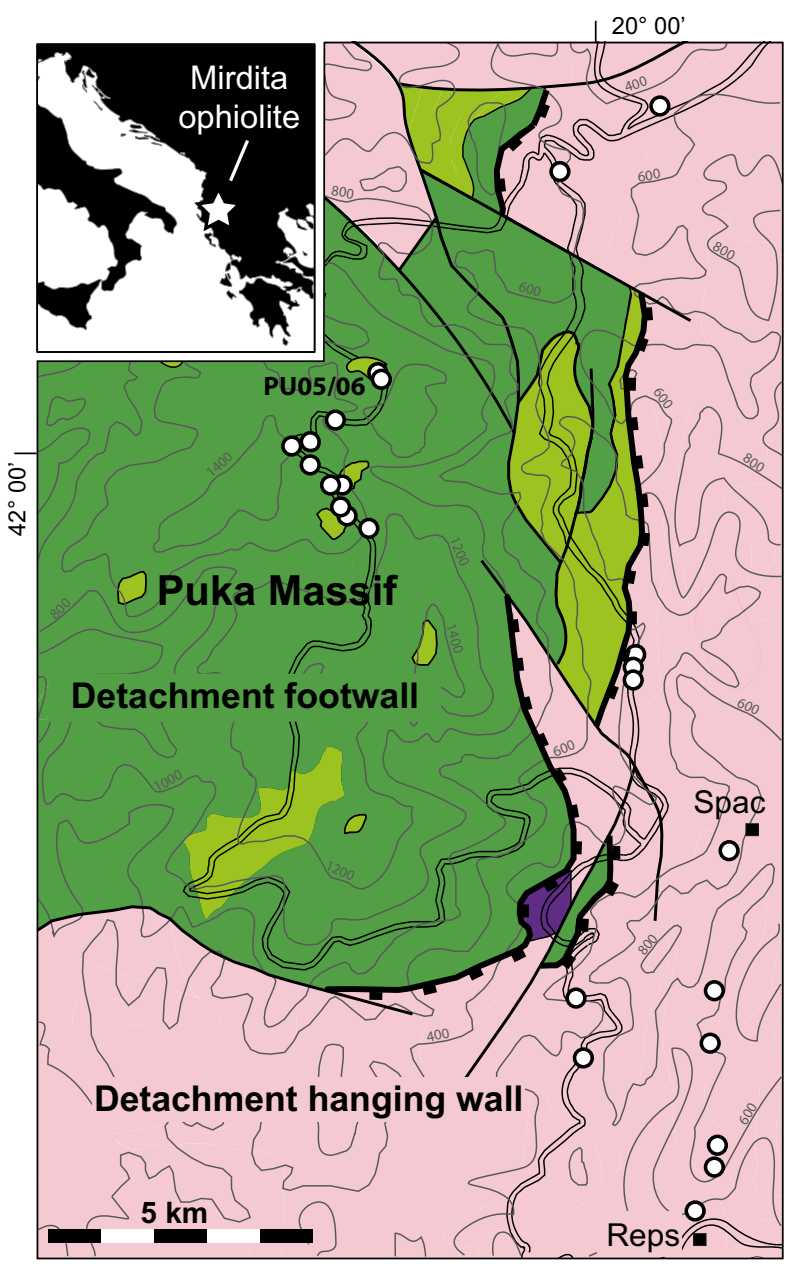

Mantle sequence $\square$ Crustal sequence (peridotite/gabbro) $\square$ (undifferentiated) Amphibolite

Inferred detachment fault Fault

Sampling site

Figure $2 \mid$ Simplified geological map of the study area in the northern Mirdita ophiolite. The Mirdita detachment fault ${ }^{19}$ separates a hanging wall sequence consisting of sheeted dikes, lavas and discrete dikes from a footwall sequence of partially serpentinized peridotites containing discrete gabbro intrusions (map adapted from the 1:200.000 Geological Map of Albania $\left.^{34}\right)$.

prior to intrusion would be thermally overprinted immediately adjacent to the contact producing a secondary magnetization identical in direction to that of the later gabbro. Remagnetization of the host peridotites after gabbro intrusion is most likely due to production of secondary magnetite during partial serpentinization ${ }^{26}$. The mean direction of magnetization of the footwall peridotites is indistinguishable from that of the upper crustal rocks of the hanging wall ( $\mathrm{PP}$ and $\mathrm{LD}+\mathrm{SD}$, respectively; Fig. 3f), suggesting remanence acquisition when blocks either side of the inferred detachment fault were in their current relative positions. The common paleomagnetic direction shared by peridotites and upper crustal rocks at the Puka Massif, combined with the statistically different, demonstrably older magnetization of the footwall gabbros, indicates that magnetization of the peridotites occurred after detachment-related rotation, but broadly coeval with magnetization of the unrotated upper crustal rocks in the hanging wall. Active detachment faulting normally occurs within a few kilometers of the ridge axial valley ${ }^{3}$ during short-lived (1-3 $\mathrm{Ma}^{4,5}$ ) periods of detachment-dominated spreading. Since major serpentinization (with associated magnetization acquisition) takes place in the footwall peridotites during faulting activity ${ }^{27}$, the age of magnetization of the peridotites and upper crustal rocks is therefore likely to be very similar (within $<3 \mathrm{Ma}$ ). Similar relationships between the age of remanence in footwall gabbros and their host peridotites have been established at OCCs associated with the Fifteen-Twenty Fracture Zone in the Atlantic ${ }^{9}$, sampled during Ocean Drilling Program Leg 209, although early stage (pre-rotation) magnetization has also been inferred for some peridotites ${ }^{11}$. A common paleomagnetic direction between footwall and hanging wall units also excludes their relative rotation during ophiolite emplacement and Alpine tectonics, further restricting footwall rotation to detachment activity during Jurassic spreading.

The statistically different mean remanence directions of footwall gabbros and hanging wall upper crustal rocks must result from relative net tectonic rotation across the intervening detachment fault. Infinite solutions exist for the orientation of the axis and the magnitude of this rotation, defining a locus that forms the great circle bisectrix of the footwall and hanging-wall paleomagnetic vectors (Fig. 4a). Rotation angle is highly sensitive to choice of rotation axis along this locus ${ }^{9,11}$. This choice may be limited by making the geologically reasonable assumption that footwall rotation occurred around a ridge-parallel axis ${ }^{9,10}$. The paleo-ridge orientation in ophiolite terranes may be determined reliably from regionally consistent orientations of dikes in the sheeted dike complex (which are considered to be emplaced vertically along axis during seafloor spreading $\left.^{17,28}\right)$. Measurement of mean dike orientations at 56 locations within the $10 \mathrm{~km}$ long section of sheeted dike complex between the town of Reps and Spac (Fig. 2) indicates a consistent pattern of sub-vertical dikes with an average NNE-SSW trend $\left(026^{\circ} / 82^{\circ}, \alpha_{95}=\right.$ $\left.5.3^{\circ}\right)$. This agrees with regional dike trends in the northern Mirdita ophiolite ${ }^{17,18}$. A single net tectonic solution for the footwall rotation (axis $=029^{\circ} / 11^{\circ}$, magnitude $=46^{\circ}$ counterclockwise) is then provided by the intersection of the mean dike orientation and the great circle bisectrix of footwall and hanging wall mean remanence directions (white star in Fig. 4a).

Confidence limits ( $\alpha_{95}$ values) on both remanence directions and the mean dike orientation result in uncertainties in these rotation parameters, generating a wasp-waisted envelope of potential great circle bisectrices and a narrow envelope of permissible dike orientations (shaded regions of Fig. 4b). To model the effect of these uncertainties, we conducted a Monte Carlo simulation, selecting 1,000 pairs of points randomly distributed within the $\alpha_{95}$ cones of confidence of the footwall and hanging wall magnetization vectors to generate 1,000 statistically acceptable great circle bisectrices. These were combined with 1,000 dike orientations randomly selected within the $\alpha_{95}$ confidence limits on the mean dike orientation, yielding 1,000 estimates of the mean rotation axis and magnitude. Figure $4 \mathrm{c}$ illustrates the resulting distributions of rotation axes and angles. The orientation of the maximum density of the cluster of rotation axes is $028^{\circ} / 16^{\circ}$, and is taken as the best estimate for the relative rotation axis in present day geographic coordinates together with the median counterclockwise rotation angle of $44.5^{\circ}$. This provides a minimum estimate of the total rotation because of the potential for early rotation of the footwall at temperatures above the magnetite Curie temperature $\left(580^{\circ} \mathrm{C}\right)$ or prior to gabbro intrusion.

The observed strike of the sheeted dikes is orthogonal to the regional emplacement WNW-ESE direction of the Mirdita ophiolite ${ }^{18}$. The sub-vertical orientation of the sheeted dikes therefore suggests that there has been only limited net tilting of the Mirdita upper crustal section during ophiolite emplacement ${ }^{17}$. Hence, the present day subhorizontal relative rotation axis was likely to have originally been subhorizontal prior to emplacement.

\section{Discussion}

Our modelled solution for footwall rotation accommodated by the Mirdita detachment (Fig. 4c) is geometrically consistent with mantle unroofing and denudation via a flexural, rolling-hinge mechanism ${ }^{12,13,29}$ 
a

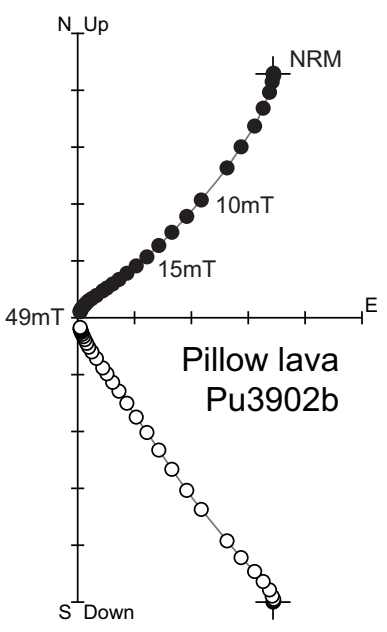

b

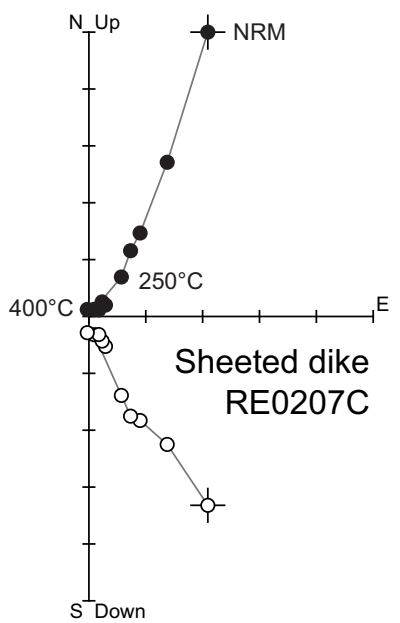

C

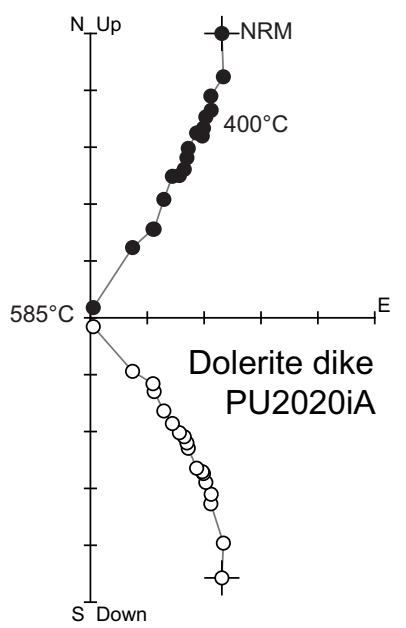

d

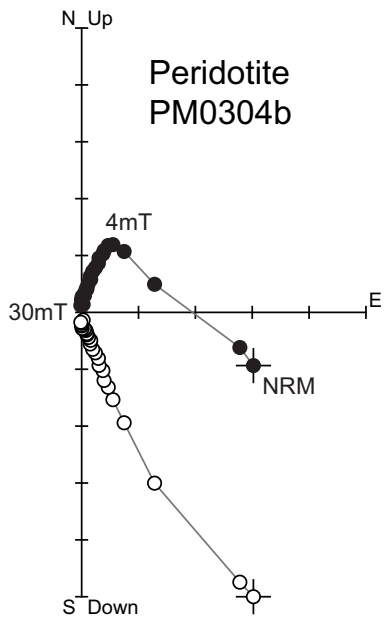

e

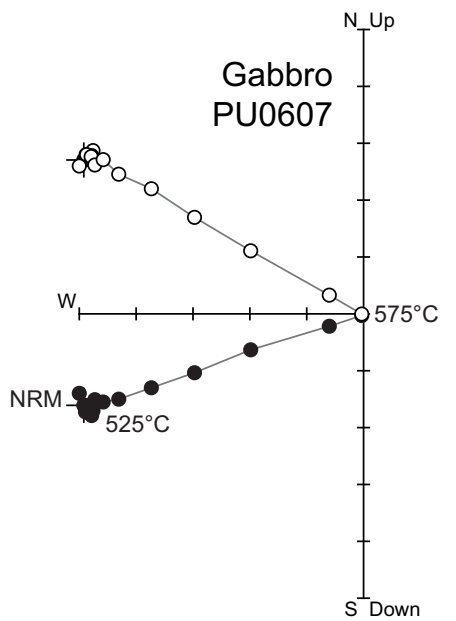

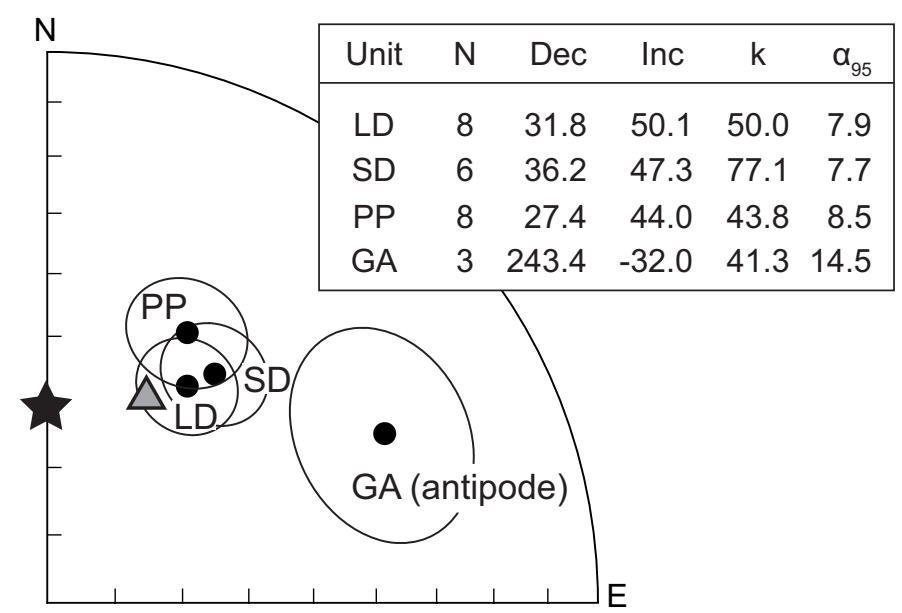

Figure 3 Summary of paleomagnetic results from the Puka Massif and surrounding region. (a-e) Representative orthogonal vector plots of thermal and alternating field (AF) demagnetization for each lithological group (in situ coordinates). Solid/open circles represent the projection of the remanence vector onto the horizontal/vertical plane, respectively; NRM, natural remanent magnetization; specified demagnetization steps are in degrees Celsius $\left({ }^{\circ} \mathrm{C}\right)$ or millitesla (mT). (f) Equal area stereographic projection of the mean directions of pillow lavas and dikes (PD), peridotites (PP), sheeted dikes (SD), and gabbros (GA), with associated $\alpha_{95}$ cones of confidence (in situ coordinates). Note that the antipode of the reversed magnetization of the gabbros is shown to allow direct comparison with other units; black star indicates the present day geocentric axial dipole (GAD) field direction for the Puka region; grey triangle indicates the expected direction for the $170 \mathrm{Ma}$ European paleopole ${ }^{22}$. Inset table: $\mathrm{N}=$ number of sampling sites; Dec $=$ declination $\left({ }^{\circ}\right)$ of the mean remanence direction; Inc $=$ inclination $\left({ }^{\circ}\right)$ of the mean remanence direction, $\mathrm{k}=$ Fisher ${ }^{32}$ precision parameter; $\alpha_{95}=$ semi-angle of the $95 \%$ cone of confidence $\left({ }^{\circ}\right)$ around the mean direction.

during detachment-mode seafloor spreading. It may be compared directly to solutions derived from core samples collected from young OCCs along the Mid-Atlantic Ridge. Paleomagnetic analyses at Atlantis Massif OCC (Integrated Ocean Drilling Program Expedition $304 / 305^{7}$ ) indicate a minimum $46^{\circ}$ footwall rotation ${ }^{10}$, making the assumption that the footwall rotation axis was horizontal (Fig. 4d). At the $15^{\circ} 45^{\prime} \mathrm{N}$ OCC, direct constraints on potential rotation axes have been derived from structural analysis of fully oriented core samples collected using a sea-bed rock drill system $^{5}$, demonstrating a $64^{\circ}$ footwall rotation around a sub-horizontal axis ${ }^{11}$ (Fig. 4e). In both of these examples of well-constrained, young OCCs, footwall rotation axes were found to be parallel to the local orientation of the Mid-Atlantic Ridge (consistent with ridge-orthogonal slip directions inferred from corrugations on exposed detachment surfaces ${ }^{2,5}$ ), supporting the key assumption used in our analysis.
Recognition of the importance of Chapman detachment-mode spreading ${ }^{8}$ is based largely on bathymetric and geophysical observations in young lithosphere formed at slow- to ultraslow-spreading rate ridges ${ }^{2-4}$. Our understanding of the tectonic processes and conditions of formation of these young structures has benefitted from direct sampling and borehole logging of OCC footwall sequences by scientific ocean drilling $2,5,7,10,11,30$. Seismic reflection profiling in older crust in the eastern Central Atlantic ${ }^{14}$ provides evidence for Cretaceous fault structures buried by later sedimentary sequences that have geometries compatible with detachment-mode spreading. However, these data provide only indirect evidence for footwall rotation in inferred ancient OCCs. The striking similarity (Fig. 4c-e) between the rotation analysis of the Mirdita detachment fault system presented here and well-constrained examples in the Atlantic ${ }^{9-11}$ now provides compelling evidence that rolling hinge rotation during detachment-mode of spreading ${ }^{8}$ also operated in the deep geological 

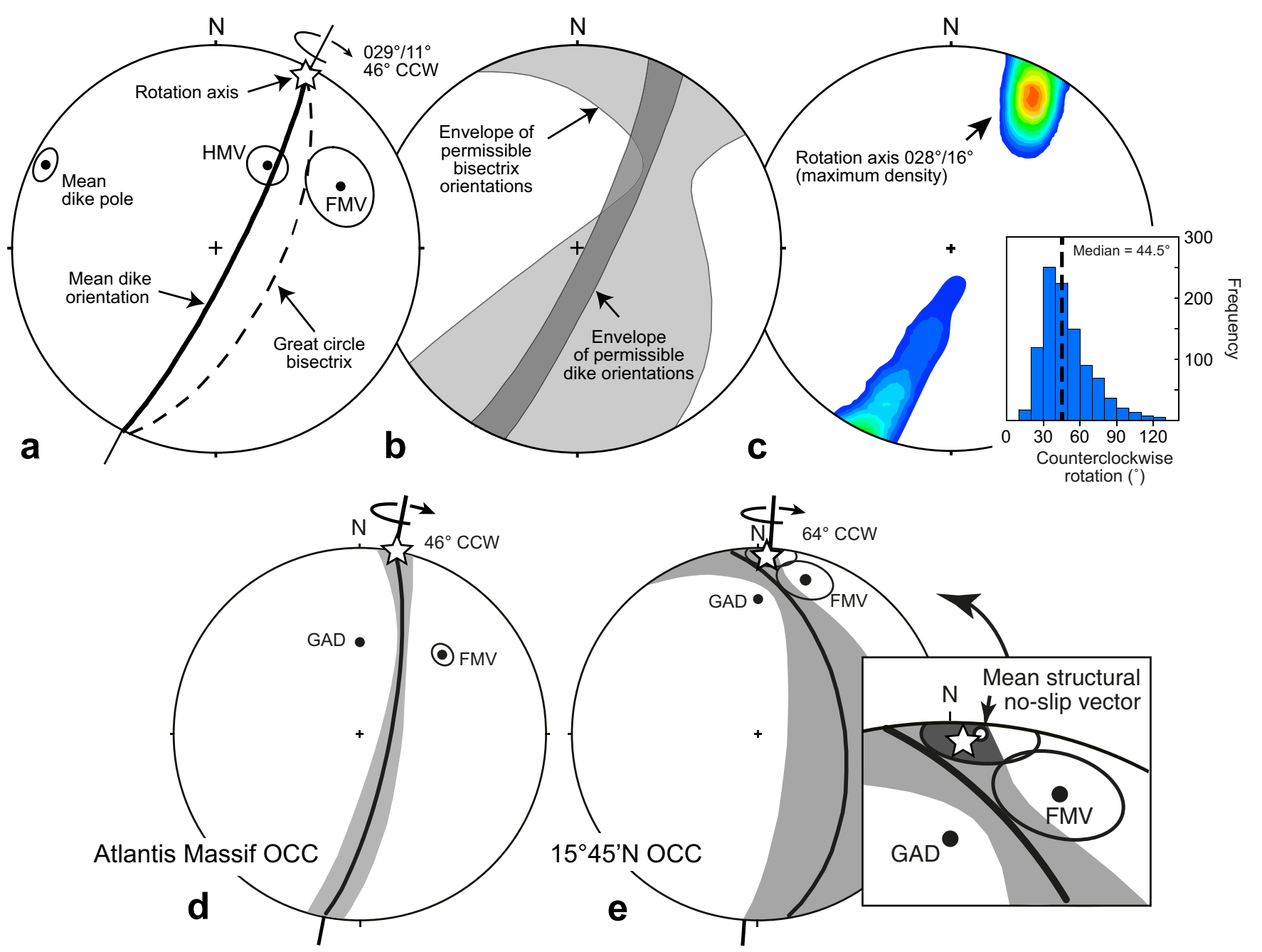

Figure 4 Equal area stereographic projections illustrating the geometry of rotation solutions for footwall rotation in the Mirdita ophiolite and young OCCs on the Mid-Atlantic Ridge. (a) Footwall rotation axes lie on the great circle bisectrix of the footwall and hanging-wall magnetization vectors (FMV and HMV, respectively). Assuming a ridge-parallel rotation axis, a single solution is found from the intersection of the mean dike orientation with this bisectrix. (b) Envelopes of bisectrix and dike orientations (grey shaded areas) resulting from $95 \%$ confidence limits on remanence vectors and the mean dike orientation. Permissible rotation solutions lie within the region of overlap of these envelopes. (c) Contouring of 1000 permissible rotation axes resulting from Monte Carlo analysis (combining 1,000 pairs of FMVs and HMVs randomly distributed within their respective $\alpha_{95}$ cones of confidence with 1,000 dike orientations randomly selected within the $\alpha_{95}$ confidence limit on the mean dike orientation). Results indicates permissible rotation axes plunging shallowly to the NNE (maximum density of the contours), with a median rotation of $44.5^{\circ} \mathrm{CCW}$ (inset). (d) Assuming simple tilting, the preferred solution (white star) of footwall rotation at Atlantis Massif oceanic core complex ${ }^{10}$ indicates $46^{\circ}$ of counterclockwise rotation around a ridgeparallel axis. The gray area represents the envelope of permissible bisectrix orientations. (e) At the $15^{\circ} 45^{\prime} \mathrm{N}$ oceanic core complex ${ }^{11}$, structural data (mean no-slip vector $=$ vector perpendicular to the slip direction) on oriented cores provide an independent control on permissible rotation axes. The gray shaded area is the envelope of permissible bisectrix orientations. Solutions that satisfy both paleomagnetic and structural constraints lie within the dark gray shaded region (inset), indicating a mean rotation of $64^{\circ}$ around a sub-horizontal, ridge-parallel axis ${ }^{11}$ (white star).

past and has been a characteristic of slow-spreading systems since at least the Jurassic.

\section{Methods}

Cores were drilled in the field using a water-cooled petrol-powered portable drill, and oriented with both sun and magnetic compasses. Natural remanent magnetizations were measured with an AGICO JR-6A spinner magnetometer and a $2 \mathrm{G}$ superconducting cryogenic magnetometer. Stepwise alternating field $(\mathrm{AF})$ demagnetization was performed using either an AGICO LDA-3 instrument or the in-line AF demagnetizing coils on the cryogenic. Stepwise thermal demagnetization was conducted using Magnetic Measurements Ltd MMTD1 and Pyrox furnaces. Demagnetization data were subject to principal component analysis using the AGICO Remasoft package ${ }^{31}$ and site mean directions calculated using Fisher statistics ${ }^{32}$.

The thermal variation of low-field magnetic susceptibility was measured in an argon atmosphere using an AGICO KLY-3/CS-3 apparatus. First-order reversal curves $^{33}$ were measured on one specimen per site using a Princeton Micromag vibrating sample magnetometer (VSM) in order to characterize the coercivity and grain size distribution of ferromagnetic minerals within samples.
1. Cann, J. R. et al. Corrugated slip surfaces formed at North Atlantic ridgetransform intersections. Nature 385, 329-332 (1997).

2. Blackman, D. K. et al. Proceedings of the Integrated Ocean Drilling Program, 304/ 305. Integrated Ocean Drill. Program, College Station, Tex (2006).

3. Smith, D. K. et al. Fault rotation and core complex formation: Significant processes in seafloor formation at slow spreading mid-ocean ridges (Mid-Atlantic Ridge, 13-15 N). Geochem. Geophys. Geosyst. 9, Q03003 (2008).

4. Escartín, J. D. et al. Central role of detachment faults in accretion of slowspreading oceanic lithosphere. Nature 455, 790-794 (2008).

5. MacLeod, C. J. et al. Direct geological evidence for oceanic detachment faulting: The Mid-Atlantic Ridge, $15^{\circ} 45^{\prime}$ N. Geology 30, 279-282 (2002).

6. MacLeod, C. J. et al. Life cycle of oceanic core complexes. Earth Planet. Sci. Lett. 287, 333-344 (2009).

7. Ildefonse, B. et al. Oceanic core complexes and crustal accretion at slow-spreading ridges. Geology 35, 623-626 (2007).

8. Escartín, J. \& Canales, J. P. Detachments in oceanic lithosphere: Deformation, magmatism, fluid flow, and ecosystems. Eos Trans. AGU, 92(4), 31 (2011).

9. Garcés, M. \& Gee, J. S. Paleomagnetic evidence of large footwall rotations associated with low-angle faults at the Mid-Atlantic Ridge. Geology 35, 279-282 (2007). 
10. Morris, A. et al. Footwall rotation in an oceanic core complex quantified using reoriented Integrated Ocean Drilling Program core samples. Earth Planet. Sci. Lett. 287, 217-228 (2009).

11. MacLeod, C. J. et al. Quantitative constraint on footwall rotations at the $15^{\circ} 45^{\prime} \mathrm{N}$ oceanic core complex, Mid-Atlantic Ridge: Implications for oceanic detachment fault processes. Geochem. Geophys. Geosyst. 12, Q0AG03 (2011).

12. Buck, W. R. Flexural rotation of normal faults. Tectonics 7, 959-973 (1988).

13. Lavier, L. L., Buck, W. R. \& Poliakov, A. N. B. Self-consistent rolling-hinge model for the evolution of large-offset low-angle normal faults. Geology 27, 1127-1130 (1999).

14. Reston, T. J. \& Ranero, C. R. The 3-D geometry of detachment faulting at midocean ridges. Geochem. Geophys. Geosyst. 12, Q0AG05 (2011).

15. Robertson, A. H. F. Late Palaeozoic-Cenozoic tectonic development of Greece and Albania in the context of alternative reconstructions of Tethys in the Eastern Mediterranean region. Int. Geol. Rev. 54(4), 373-454 (2012).

16. Bortolotti, V. et al. Geology and petrology of ophiolitic sequences in the Mirdita region (Northern Albania). Ofioliti 21, 3-20 (1996).

17. Nicolas, A., Boudier, F. \& Meshi, A. Slow spreading accretion and mantle denudation in the Mirdita ophiolite (Albania). J. Geophys. Res. 104(B7), 15155-15167 (1999).

18. Meshi, A. et al. Structure and tectonics of lower crustal and upper mantle rocks in the Jurassic Mirdita ophioilites, Albania. Int. Geol. Rev. 52(2-3), 117-141 (2010).

19. Tremblay, A., Meshi, A. \& Bédard, J. H. Oceanic core complexes and ancient oceanic lithosphere: Insights from Iapetan and Tethyan Ophiolites (Canada and Albania). Tectonophysics 473, 36-52 (2009).

20. Morris, A. \& Anderson, M. W. Palaeomagnetic results from the Baër-Bassit ophiolite of northern Syria and their implication for fold tests in sheeted dyke terrains. Phys. Chem. Earth 27, 1215-1222 (2002).

21. Walker, J. D. \& Geissman, J. W. 2009 GSA Geologic Time Scale. GSA Today 19(4), 60-61 (2009).

22. Besse, J. \& Courtillot, V. Apparent and true polar wander and the geometry of the geomagnetic field over the last 200 Myr. J. Geophys. Res. 107(B11), 2300 (2002).

23. Gee, J. S. \& Kent, D. V. in Treatise on Geophysics, Geomagnetism (ed Kono, M.) 5 , 455-507 (Elsevier, Amsterdam, 2007).

24. Herrero-Bervera, E. et al. in The Earth's Magnetic Interior (eds Petrovský et al.) 153-168 (IAGA Special Sopron Book Series 1, Springer Science + Business Media, 2011).

25. Speranza, F. et al. Paleomagnetic evidence for Cenozoic clockwise rotation of the external Albanides. Earth Planet. Sci. Lett. 129, 121-134 (1995).

26. O’Hanley, D. S. Serpentinites (Oxford University Press, New York, 1996).

27. Andreani, M. et al. Dynamic control on serpentine crystallization in veins: Constraints on hydration processes in oceanic peridotites. Geochem, Geophys. Geosyst. 8, Q02012 doi:10.1029/2006GC001373 (2007).
28. Ildefonse, B., Nicolas, A. \& Boudier, F. Evidence from the Oman ophiolite for sudden stress changes during melt injection at oceanic spreading centres. Nature 366, 673-675 (1993).

29. Buck, W. R., Lavier, L. L. \& Poliakov, A. N. B. Modes of faulting at mid-ocean ridges. Nature 434, 719-723 (2005).

30. Pressling, N., Morris, A., John, B. E. \& MacLeod, C. J. The internal structure of an oceanic core complex: An integrated analysis of oriented borehole imagery from IODP Hole U1309D (Atlantis Massif). Geochem. Geophys. Geosyst. 13, Q04G10 (2012).

31. Chadima, M. \& Hrouda, F. Remasoft 3.0 a user-friendly paleomagnetic data browser and analyzer. Travaux Géophysiques 27, 20-21 (2006).

32. Fisher, R. A. Dispersion on a sphere. Proc. R. Soc. London 217, 295-305 (1953).

33. Roberts, A. P., Pike, C. R. \& Verosub, K. L. FORC diagrams: A new tool for characterizing the magnetic properties of natural samples. J. Geophys. Res. 105, 28, 461-28, , 475 (2000).

34. ISPGJ-IGJN. Geological Map of Albania, scale 1 : 200000. Tirana, Albania (2002).

\section{Acknowledgments}

This work was funded by an EU FP7 Marie Curie Intra-European Fellowship to M.M. We are grateful to Prof Kujtim Onuzi and Prof Ibrahim Milushi (Institute of Geosciences, Polytechnic University of Tirana, Albania) for logistical support, and Endri Leka and Gezim Calldani for help during sampling.

\section{Author contributions}

M.M., A.M. and M.A. wrote the main manuscript text. M.M. and A.M. prepared the figures. A.M. performed the Monte Carlo analysis and M.M. carried out the paleomagnetic analyses.

\section{Additional information}

Competing financial interests: The authors declare no competing financial interests.

How to cite this article: Maffione, M., Morris, A. \& Anderson, M.W. Recognizing detachment-mode seafloor spreading in the deep geological past. Sci. Rep. 3, 2336; DOI:10.1038/srep02336 (2013).

(c) (i) $\Theta$ This work is licensed under a Creative Commons Attribution-

(1) No No Nommercial-NoDerivs 3.0 Unported license. To view a copy of this license, visit http://creativecommons.org/licenses/by-nc-nd/3.0 